\author{
先天性心疾患における 3DRA の有用性 \\ 石垣 瑞彦 $^{1)}$, 金 成海 $^{1)}$, 松尾 久実代 ${ }^{1)}$, 鬼頭 真知子 ${ }^{1)}$, 藤岡 泰生 ${ }^{1)}$,

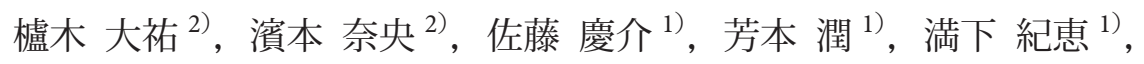 \\ 新居 正基 ${ }^{1)}$, 田中 靖彦 ${ }^{1)}$, 坂本 喜三郎 ${ }^{3)}$, 小野 安生 ${ }^{1)}$ \\ 1) 静岡県立こども病院循環器科 \\ 2) 静岡県立こども病院循環器集中治療科 \\ 3) 静岡県立こども病院心臓血管外科
}

\title{
Efficacy of Three-Dimensional Rotational Angiography as a Diagnostic and Interventional Modality for Congenital Heart Disease
}

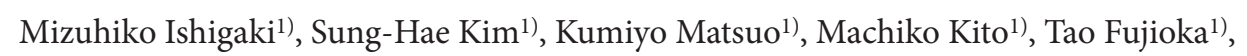 \\ Daisuke Hazeki ${ }^{2)}$, Nao Hamamoto ${ }^{2)}$, Keisuke Sato ${ }^{1)}$, Jun Yoshimoto ${ }^{1)}$, Norie Mitsushita ${ }^{1)}$, \\ Masaki Nii ${ }^{1)}$, Yasuhiko Tanaka ${ }^{1)}$, Kisaburo Sakamoto ${ }^{3)}$, and Yasuo Ono ${ }^{1)}$ \\ ${ }^{1)}$ Department of Cardiology, Shizuoka Children's Hospital, Japan \\ ${ }^{2)}$ Department of Cardiac Intensive Care Unit, Shizuoka Children's Hospital, Japan \\ ${ }^{3)}$ Department of Crdiovascular surgery, Shizuoka Children's Hospital, Japan
}

\begin{abstract}
Background: Lesions of congenital heart disease require stereoscopic understanding, which can be enhanced by three dimensional imaging. In Shizuoka Children's Hospital, three-dimensional rotational angiography (3DRA) is in use since 2013.

Purpose: To report the efficacy of 3DRA in congenital heart disease.

Objective and Methods: We evaluated the advantage of 3DRA in 24 patients. Secondly, we reviewed 15 patients who had a single target lesion in the pulmonary artery after Rastelli procedure, visualized on 3DRA $(n=5)$ or CT $(n=10)$ at the time of intervention, between 2010 and 2016. Procedural parameters were compared between the two groups.

Results: All reconstructed 3DRA images provided adequate diagnostic quality and by Likert scale, classified as either "essential" or "very useful" for pre-operative or interventional planning in $75 \%$ of patients, especially in complex vascular lesions. No complications occurred. There was no significant difference with respect to procedure time, fluoroscopy time, radiation dose of angiography between 3DRA and CT. Total contrast media used in 3DRA group $(3.9 \mathrm{~mL} / \mathrm{kg})$ was significantly lower than that in the CT group $(5.9 \mathrm{~mL} / \mathrm{kg} ; p=0.003)$.

Conclusions: 3DRA is a safe and effective modality in pediatric cardiovascular area. Wide-angled, stereoscopic image reconstruction allows for a more objective evaluation. Use of 3DRA was comparable to that of CT with respect to procedure time, fluoroscopy time, and radiation dose. Total contrast media used was significantly less in the former.
\end{abstract}

Keywords: three-dimensional rotational angiography, three-dimensional radiological image, intervention, congenital heart disease

2015 年 8 月 26 日受付, 2016 年 11 月 2 日受理

著者連絡先 : ₹420-8660 静岡県静岡市葵区漆山 860 静岡県立こども病院 循環器科 石垣瑞彦

doi: $10.9794 /$ jspccs.32.498

(C) 2016 Japanese Society of Pediatric Cardiology and Cardiac Surgery 
背景：立体的な病変の把握が大切な先天性心疾患において, 三次元撮影はその精度を大きく向上させ うるツールである. 当院では, 2013 年より 3D Rotational Angiography（3DRA）を導入し, 病変の立 体的な把握抢よび Intervention に利用している.

目的：3DRA の小児循環器領域での有用性を報告する.

方法：はじめに当院で 3DRA を施行した 24 症例を対象として, 小览循環器領域での有用性を後方視的 に検討した. 次に 2010 年 1 月〜2016 年 6 月に当院で Rastelli 術後の肺動脈狭窄に対して経皮的バルー ン血管形成術を施行した 46 例から, 3DRA もしくは CT を併用しかつ治療対象が一病変であった 15 例を抽出 (3DRA 群 5 例, CT 群 10 例) 乙手技時間, 透視時間, 造影剤使用量, 被曝線量を比較検討 した.

結果 : 3DRA の対象血管は肺動脈 22 例 /大動脈 2 例で, 全例評価可能であった. 画像評価として従来 法を上回る 'essential/very useful' は全体の 75\%で, 特に複雑な形態の血管の描出に優れていた. 被曝 線量は，対象血管が肺動脈の場合，3DRA1 回は二方向性血管撮影 2.8 回に相当した. 血管拡張術は 13 例（バルーン血管形成術 11 例, ステント留置 2 例）で, うち 5 例では, 3DRA 画像をもとに全セッショ ン single plane 使用であった. CT 群との比較では, 手技時間, 透視時間, CT を除く造影剤使用量, 被曝線量は同等であった一方で, 総造影剤使用量は 3DRA 群 $3.9 \mathrm{~mL} / \mathrm{kg}$ : CT 群 $5.9 \mathrm{~mL} / \mathrm{kg} \quad(p=0.003)$ であった。

結論：3DRA は, 小児循環器領域でも安全に施行可能で従来法にはない広角的, 立体的な画像構築に より, より客観的な診断, 評価に寄与する可能性が示唆された. さらにインターベンションにおいて は, 手技時間, 透視時間, 造影剤使用量, 被曝線量などの面で従来法と比べ遜色なく, CT 併用群に比 し総造影剂使用低減が可能であった。

\section{背 景}

3D Rotational Angiography（3DRA）は，回転する フラットパネル・ディテクター（FPD）を用いた血 管撮影法で, 2006 年頃より主に脳神経外科領域で脳 動脈瘤の形態診断や空間的位置関係の把握, 治療に応 用されている. その後, 腹部血管造影, 冠動脈造影や カテーテルアブレーション, 近年では, 構造的心疾患 (structural heart disease) へと適応が拡大され, 画像 診断，特にインターベンションのツールとして利用 されている ${ }^{1-8)}$. 先天性心疾患の領域では, 2010 年以 降, 従来の二次元的画像では観察困難な病変の描出に 優れ，形態診断やインターベンションに新たな恩恵を もたらすと報告されている ${ }^{9,10)}$. 読影者の経験に基づ く想像, CT や心エコー図といった他のモダリティか らの類推に代わる三次元画像ツールとして, 当科では 2013 年より 3DRA を導入している.

\section{目的}

3DRA の撮影方法, 使用状況の実際を紹介し, 小児 循環器領域での有用性を報告する.

\section{方 法}

はじめに 2013 年 6 月から 2016 年 6 月に当院で
3DRA を施行した 24 症例を対象として，3DRA の特 徵, 使用方法, 描出可能な病変等, 小览循環器領域で の使用経験および有用性を後方視的に検討した．画像 評価としては, Table 1 に示す Ellis ら ${ }^{11)}$ の報告した 5 段階の Likert scale を用いて小児循環器専門医 2 名 で従来の二方向性血管造影と比較し後方視的に検討し た. 被曝線量に関しては，対象血管に二方向性血管造 影と 3DRA が同時に施行された症例から比較検討し た.

次に, 2010 年 1 月から 2016 年 6 月に当院で Rastelli 術後の肺動脈に対して経皮的バルーン血管形成術 (balloon angioplasty: BAP) を施行した 46 例から, 3DRA もしくは CT を併用しかつ治療対象が一病変で あった 15 例を抽出した.この 15 例（3DRA 群 5 例, CT 群 10 例) で, 手技時間, 透視時間, 造影剤使用量, 被曝線量を比較検討した. 被曝線量は, 実効線量への 換算式がモダリティごとに異なり仮定等も含まれ正確 な合算值を得ることは難しいため, 両者の血管造影で の数值を比較した。 な打画像撮影として，2013 年以 降は3DRA を基本とし, 直近の conduit 交換など外 科介入が予想される症例では CT が選択された。

2 群間の比較には, Mann-WhitneyのU 検定を用 い, 有意水準 $p<0.05$ を有意差ありとした. 3DRA を 含む血管造影, CT 検査ともインフォームドコンセン 卜を得て行い, 臨床研究に関しては後方視的研究のた め倫理委員会等の審査は不要と判断された. 
Table 1 Modified Likert scale concerning the diagnostic utility of flat-detector

$\begin{array}{ll}\text { Misleading } & \text { Misleading information for pre-operative planning or intervention. } \\ \text { Not useful } & \text { No useable information for pre-operative planning or intervention. } \\ \text { Useful } & \begin{array}{l}\text { Useful information for pre-operative planning or intervention, but only minimally superior to the already available } \\ \text { information of angiographies. }\end{array} \\ \text { Very useful } & \text { The scan added important information to what was already available. } \\ \text { Essential } & \begin{array}{l}\text { The surgery or the intervention could not have been performed appropriately without the additional information } \\ \text { provided. }\end{array}\end{array}$

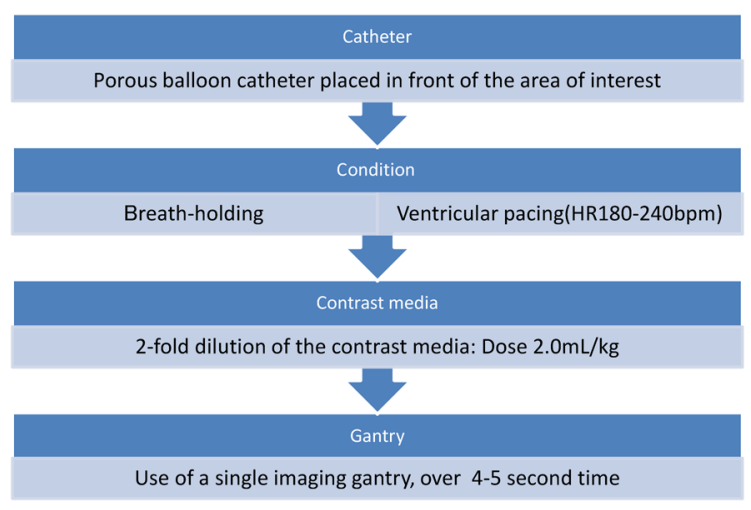

Fig. 1 3DRA rendering protocol

\section{撮影方法}

3DRA の実際の撮影方法の詳細を示す。血管撮影装 置は, Siemens 社製 AXIOM Artis dBA を, 3D 画像 構築ワークステーションとして同社の InSpace 3D を 使用した。撮影条件は, Zahn らの報告 ${ }^{10)}$ に従い, 正面 FPD を $40^{\circ}$ /秒の回転速度で $200^{\circ}$ の画像収集と し，2 倍希釈の造影剤 $1 \sim 2 \mathrm{~mL} / \mathrm{kg}$ を関心領域の手前 から多側孔のカテーテルで注入, 全身麻酔下, 呼吸 停止，心室オーバードライブ下での撮影を基本とし た (Fig. 1/Video 1). 実際の撮影に際しては, 麻酔器 等の周辺環境を整備したうえで正面管球のCアーム が安全に回転できることを確認し，撮影手技を開始 している. ペーシングは, 右心系造影時は経大動脈 的に $2 \mathrm{~F} 8$ 極電極力テーテルを左心室内に留置, 左心 系造影時には $4 \mathrm{~F}$ または $5 \mathrm{~F}$ の電極カテーテルを経静 脈的に右心室に留置, 年齢や基礎の心拍数を考慮し HR180 240 程度でのオーバードライブとした. 例外 として, 血流が層流に近いグレン, フォンタン循環回 路の肺動脈撮影等ではオーバードライブを併用してい ない。造影剤に関しては, 体格, Blalock-Taussig 短 絡の存在など注入部位, 血管形態, 弁逆流等を考慮し 決定している. 右室流出路からの肺動脈造影では概ね $2 \mathrm{~mL} / \mathrm{kg}$ の使用で良好な造影効果が得られている. 撮 影後, データをワークステーションに転送し, 構築さ
れる Raw dataの 3D 画像から胁骨など不要部分を任 意の方法に回転しながら除去し, 目的部分を取り出す ことで $3 \mathrm{D}$ 再構築画像が完成する. 実際の画像を提示 する (Video 2A, B).

一方で CT は, Siemens 社製 SOMATOM sensation を使用した 64 列 MDCT で，非心電同期，末梢静脈 路からの造影剤注入 $(2 \mathrm{~mL} / \mathrm{kg})$ で施行した。

\section{結 果}

\section{DRA の小児循環器領域での使用および画像評価，被 曝線量}

3DRA 施行 24 症例の基礎疾患の内訳は，肺動脈閉 鎖／心室中隔欠損（PAVSD: pulmonary atresia with ventricular septal defect) / 主要体肺動脈側副血行路 (MAPCA: major aorto-pulmonary collateral arteries) 12 例, 肺動脈閉鎖 / 心室中隔欠損 3 例, ファロー四 徵症 2 例（MAPCA1 例を含む）, 大動脈縮窄 2 例, 左心低形成症候群 2 例, 両大血管右室起始／肺動脈閉 鎖, 修正大血管転位, 大動脈離断が各 1 例であった. その内 13 例が Rastelli 術後症例であった（Table 2). 3DRA による評価対象病変は, MAPCA を含む肺動 脈が 22 例, 大動脈が 2 例で, 3D 再構築により任意 の角度からの病変観察が可能であった. 全例で 3DRA に加え従来の一方向ないし二方向の血管撮影を併用し 診断および治療を行った. 24 症例中 13 例で経皮的血 管拡張術が施行（Rastelli 術後症例 8 例）され，治療 対象病変は肺動脈 11 例，大動脈 2 例であった．まず 対象病変に対する 3 DRA を撮影し，その他の造影を 施行中に $3 \mathrm{D}$ 再構築を施行, 再構築の所要時間は概ね 5 分以内であった。再構築画像をもとに病変観察の最 適角度を決定の上，同角度で治療を実施した。治療手 技は BAP が 11 例，ステント留置が 2 例であった。 このうち 5 例では, 3DRA 画像をもとに治療は一方 向の血管撮影で完結された，全例で合併症なく治療が 完遂された。

Likert scale を用いた画像評価では, "essential”; 1 例 (4.2\%), "Very useful”; 17 例 (70.8\%), "Useful”; 6 
Table 2 Study population

\begin{tabular}{|c|c|c|c|c|c|c|c|c|c|}
\hline case & Age & Diagnosis & $\begin{array}{c}\text { Body } \\
\text { weight } \\
(\mathrm{kg})\end{array}$ & Site & $\begin{array}{l}\text { Contrast media } \\
\text { (2-fold dilution) }\end{array}$ & $\begin{array}{c}\text { Pacing } \\
\text { HR }\end{array}$ & $\begin{array}{l}\text { Likert } \\
\text { scale }\end{array}$ & additional information & Intervention \\
\hline 1 & $9 y$ & PAVSD/MAPCA s/p.UF/Rastelli RVOTO & 46 & RVOT & 45 & 180 & 4 & $\mathrm{D}$ & BVP \\
\hline 2 & $9 y$ & PAVSD/MAPCA s/p.UF/Rastelli RVOTO & 26 & RVOT & 30 & 180 & 4 & $B, D$ & - \\
\hline 3 & $3 y$ & PAVSD/MAPCA s/p.UF/BTS & 11 & BTS & 12 & 200 & 4 & $B, D$ & - \\
\hline 4 & $2 y$ & ccTGA,DORV,IAA, Ebstein s/p.DSO(Senning/Jatene) PABS & 11 & RVOT & 24 & 220 & 4 & A (ribbon stenosis), B, D & - \\
\hline 5 & $3 y$ & PAVSD/MAPCA s/p.UF/BTS & 12 & BTS & 20 & 200 & 3 & $B, D, F$ & - \\
\hline 6 & $6 y$ & PAVSD/MAPCA s/p.BTS & 15 & BTS & 15 & 180 & 3 & $B, D, F$ & - \\
\hline 7 & $8 y$ & PAVSD/MAPCA,APW s/p.UF/Rasteli PABS & 25 & RVOT & 50 & 180 & 3 & $B, D$ & - \\
\hline 8 & $6 y$ & PAVSD/MAPCA,PAPVC s/p.UF/Rastelli RVOTO, PABS & 19 & RVOT & 35 & 180 & 4 & A (PA torsion), B, D & - \\
\hline 9 & $5 y$ & TOF/MAPCA s/p.UF/palliativeRastelli PABS & 15 & RVOT & 30 & 200 & 4 & $B, D, F$ & - \\
\hline 10 & $1 y$ & CoA & 11 & Ao & 20 & 240 & 4 & $D, E$ & BAP \\
\hline 11 & $2 y$ & TOF s/p.ICR PABS & 13 & RVOT/SVC & 25 & 210 & 4 & C, D & Stent-imp \\
\hline 12 & $6 y$ & DORV,PA s/p.Rastelli PABS & 12 & RVOT & 25 & 180 & 3 & A (PA torsion), B, D & BAP \\
\hline 13 & $1 y$ & $\mathrm{CoA}$ & 11 & Ao & 25 & 240 & 4 & $\mathrm{D}, \mathrm{E}$ & BAP \\
\hline 15 & $12 y$ & HLHS s/p.TCPC PABS & 37 & SVC & 45 & - & 4 & A (ribbon stenosis), D & Stent-imp \\
\hline 16 & $1 y$ & PAVSD/MAPCA s/p.UF/Rastelli PABS & 9 & RVOT & 20 & 240 & 5 & A (PA torsion), D, E & BAP \\
\hline 17 & $12 y$ & IAA,AS s/p.Norwood/Rastelli PABS & 60 & RVOT & 60 & 180 & 4 & A (ribbon stenosis), B, D & BAP \\
\hline 18 & $4 y$ & PAVSD s/p.Rastelli PABS & 13 & RVOT & 25 & 180 & 4 & A (ribbon stenosis), B, D, E & BAP \\
\hline 19 & $7 y$ & PAVSD/MAPCA s/p.UF/palliativeRastelli PABS & 19 & RVOT & 40 & 200 & 4 & $B, D, E, F$ & BAP \\
\hline 20 & $7 y$ & PAVSD/MAPCA s/p.UF/palliativeRastelli PABS & 15 & RVOT & 30 & 200 & 4 & $\mathrm{~A}$ (PA torsion), $\mathrm{B}, \mathrm{D}, \mathrm{F}$ & TAE-MAPCA \\
\hline 21 & $2 y$ & HLHS s/p.TCPC PABS & 13 & Ao/SVC & 30 & 210 & 3 & A (ribbon stenosis), B, C, D & TAE-APCA \\
\hline 22 & $15 y$ & PAVSD s/p.Rastelli PABS & 42 & RVOT & 60 & 180 & 3 & $\mathrm{~A}$ (PA torsion), D, E & BAP \\
\hline 23 & $2 y$ & PAVSD/MAPCA s/p.UF/BTS PABS & 10 & BTS & 12 & 210 & 4 & $B, D, F$ & BAP \\
\hline 24 & $4 y$ & PAVSD/MAPCA s/p.UF/Rastelli PABS & 12 & RVOT & 25 & 180 & 4 & $\mathrm{~A}$ (PA torsion), $\mathrm{B}, \mathrm{D}, \mathrm{F}$ & - \\
\hline
\end{tabular}

PAVSD: pulmonary atresia with ventricular septal defect, MAPCA: major aorto-pulmonary collateral arteries, ccTGA: congenitally corrected transposition of the great arteries, DORV: double outlet right ventricle, IAA: interruption of aortic arch, PABS: pulmonary artery branch stenosis, APW: aortopulmonary window, PAPVC: partial anomalous pulmonary venous conection, TOF: tetralogy of Fallot, CoA: coarctation of aorte, PA: pulmonary atresia, HLHS: hypoplastic left heart syndrome, AS: aortic stenosis, UF: unifocalization, RVOTO: right ventricular outflow tract obstruction, BTS: Blalock-Taussig shunt, DSO: double switch operation, ICR: intracardiac repair, TCPC: total cavopulmonary connection, BVP: balloon valvuloplasty, BAP: balloon angioplasty, Stent-imp: stent implantation. TAE: transcatheter arterial embolization, APCA: aortopulmonary collateralartery. A: Mechanism of stenosis. B: Simultaneous visualization of multifocal legions. C: Three-dimensional positional relationship. D: Three-dimensinal visualization of stenotic legions. E: Determination of working angle. F: Accurate evaluation of the remaining lung segment.

例 (25.0\%) で “Not useful”や “Misleading”例はみら れなかった，全体の 75\%を占めた “essential”, “Very useful” 症例では, 'ribbon stenosis’とよばれる体軸の 前後方向の狭窄 ${ }^{10)}$ (Fig. 2, Fig. 3B) や屈曲, ねじれ （Fig. 4D）など狭窄の形態的な機序, 複数病変の同時 描出（Fig. 5）など従来法を上回る画像情報が得られ た (Table 2). Fig. 3C, D および Fig. 6 に非心電同期 の 64 列 MDCT および 3DRA 画像を提示する. 画像 のように3DRA では CT に比してより末梢の肺動脈 の描出精度が高く, クリップや胸骨ワイヤー等人工物 の影響が少ない（Fig. 4）ため, MAPCA 症例の残存 肺区域（Fig. 5）や人工物周囲のより精密な評価が可 能あった. また MDCT では 3DRA に比して狭窄部位 が大きく描出される傾向にあった。 一方で, 3DRA は 血管造影による対象血管を限定した撮影のため, CT のように静脈, 心室, 心房, 気管, 肺など全体を含む 描写は不可能であった.
次に被曝線量に関して, 通常の二方向性血管造影打 よび3DRA が同一セッションで施行された症例を提 示する (Table 3). DAP (dose area product) を通常 の血管造影の正面／側面の合算值および 3DRA で比 較すると, 3DRA1 回分が通常の血管造影 2.8 回分に 相当した. さらに，肺動脈のインターベンション時に 一般に行われる正面管球を頭側または尾側にふって撮 影した場合には, 3DRA1 回分が通常の血管造影 2.3 回分に相当した.

\section{インターベンションでの 3DRA 群と CT 群の比較} (Table 4)

全例, 一病変の肺動脈狭窄に対して BAP が施行さ れた Rastelli 術後症例で, 基礎疾患の内訳は, 3DRA 群 5 例：PAVSD/MAPCA2 例, PAVSD, 両大血管 右室起始/肺動脈閉鎖, 大動脈離断が各 1 例, CT 群 10 例：完全大血管転位 3 型, ファロー四徵症／ 

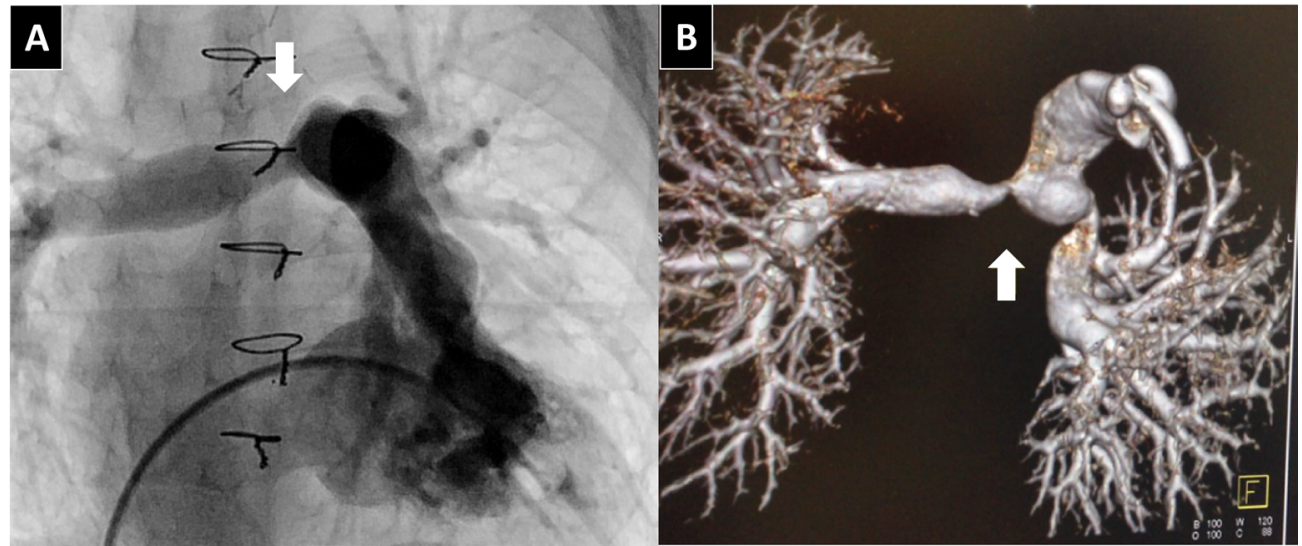

Fig. 2 Arbitrary reference plane

A: Antero-posterior view of the conventional angiogram of congenitally corrected transposition of the great arteries repaired by double switch operation in a 2-years-old boy. B: Reconstructed 3DRA image from caudal side. Arrows indicate the right pulmonary artery bifurcation stenosis (so called "ribbon stenosis") which is better delineated antero-posteriorly in 3DRA images.

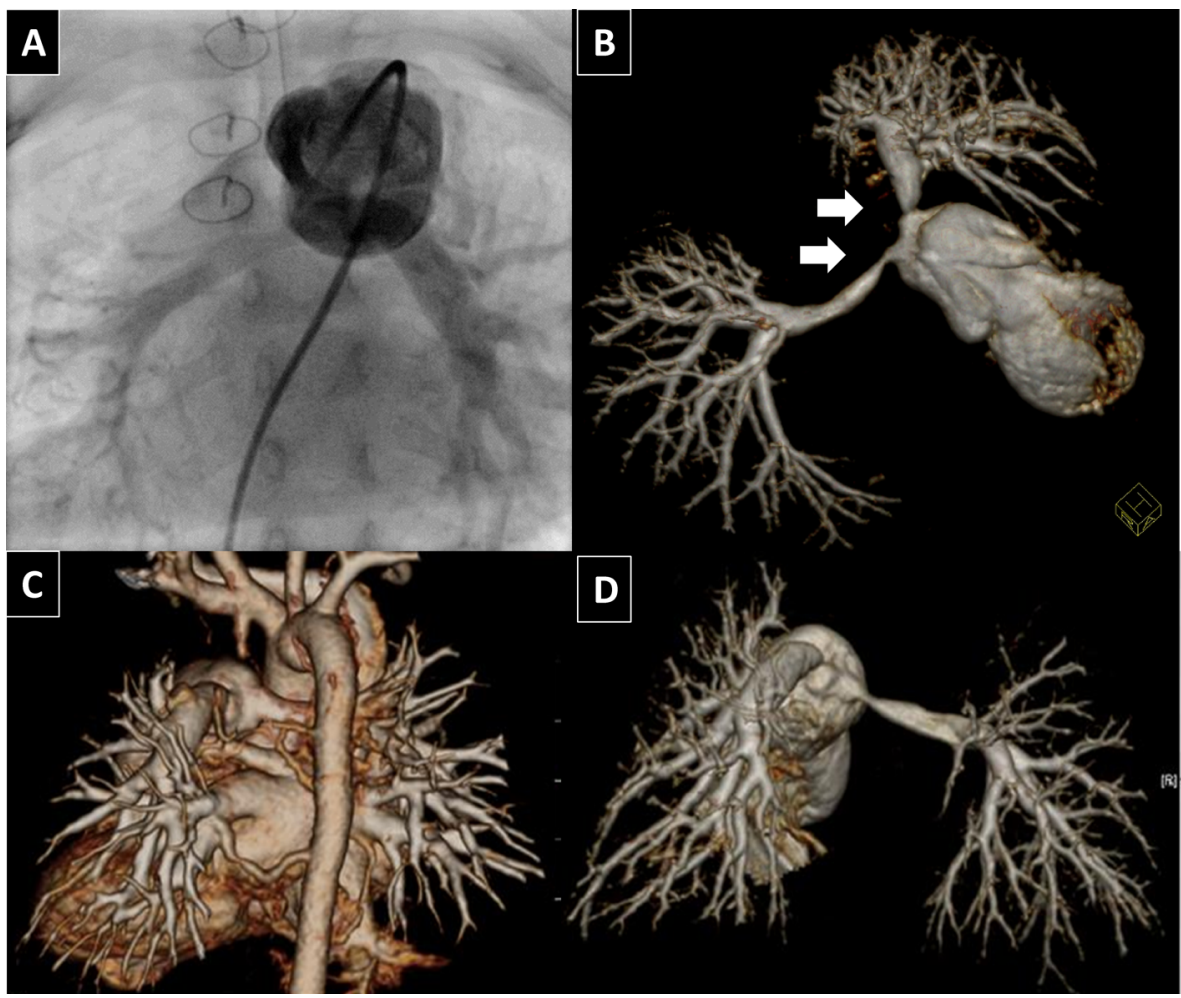

Fig. 3 Case No. 1

A: Antero-posterior view of conventional angiogram of pulmonary atresia with ventricular septal defect repaired by Rastelli procedure in a one-years-old girl. (LAO8 $/ \mathrm{CAU} 41^{\circ}$ ). We were able to grasp the diameter difference, but did not obtain clear visualization of the stenosis. B: Reconstructed 3DRA image indicated the right and left pulmonary artery bifurcation stenosis (so called "ribbon stenosis") which is better delineated anteroposteriorly (RAO44\% CRA71 ${ }^{\circ}$ ). C and D: Comparison of reconstructed 3DCT (64-row multi-detector computed tomography) image (C) and reconstructed 3DRA (D) images.

MAPCA，両大血管右室起始／肺動脈閉鎖が各 2 例， PAVSD/MAPCA, 大動脈離断, 総動脈管症, 肺動脈 弁欠損が各 1 例であった.
2 群間の年齢や体重に有意差はみられず，血管造 影検査 1 セッションあたりの手技時間, 透視時間, 被曝線量, 造影剂使用量について検討した. 3DRA 


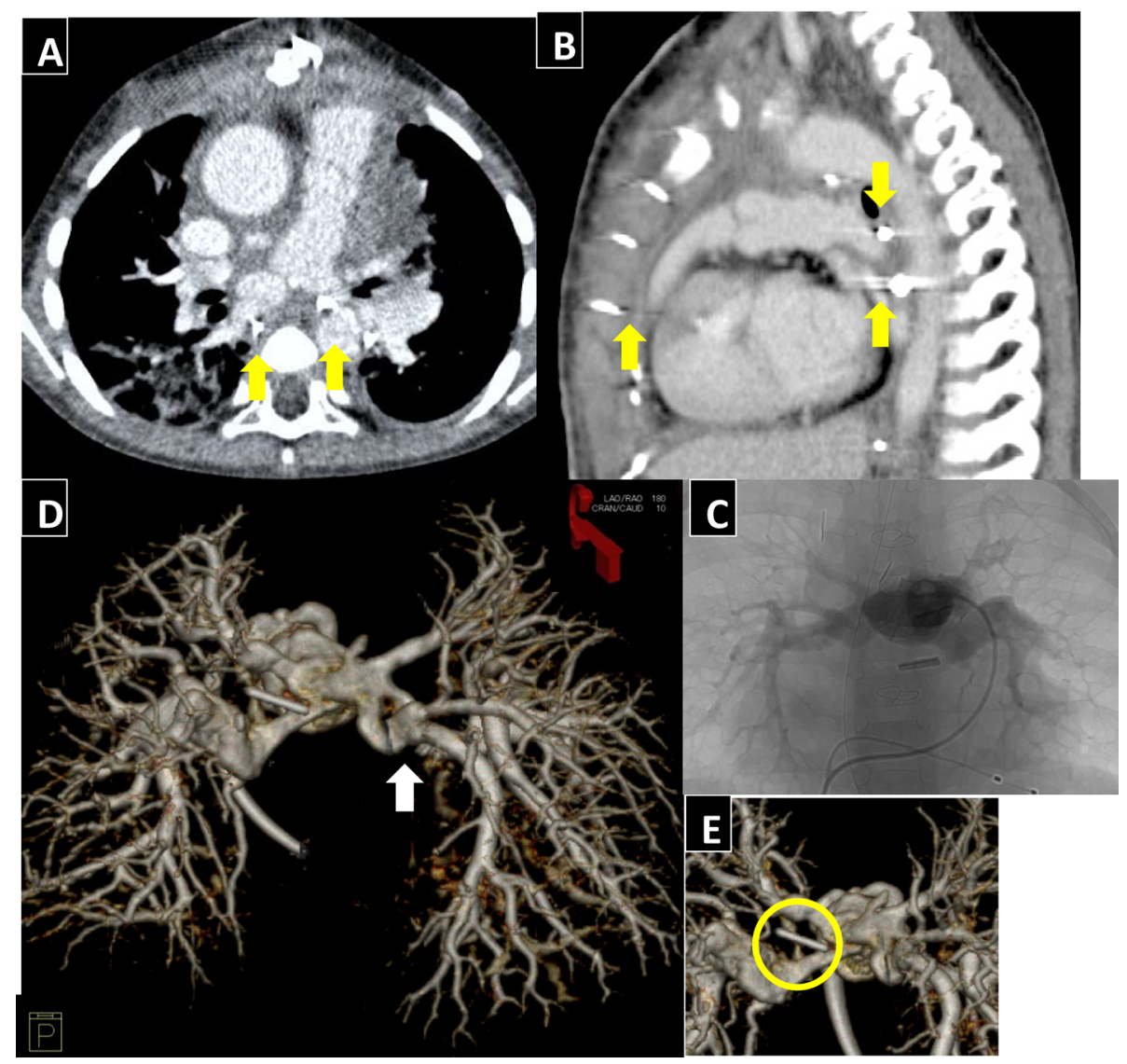

Fig. 4 The images of pulmonary artery with metallic surgical material

$A$ and $B$ : CT angiogram (horizontal (A) and sagittal (B) view) of pulmonary atresia with ventricular septal defect and major aorto-pulmonary collateral arteries (MAPCA) repaired by Rastelli procedure in a 4-years-old girl. The arrows indicate the halation. C: 3DRA of pulmonary artery. D and E: Reconstructed 3DRA image (C:LAO180\%CRA10 , $\left.\mathrm{D}: \mathrm{RAO} 160^{\circ} / \mathrm{CRA} 0^{\circ}\right)$. The arrow indicates pulmonary artery stenosis by PA torsion. The circle indicates hemo-clip placed for ligation of dual supplying MAPCA during at previous surgery. The image quality was less affected by the clip and sternum wire.

群, CT 群の順で実際の数值を示す．手技時間：121 分 $(114 \sim 212)$ vs 121 分 $(76 \sim 196) ; p=0.46$. 透視 時間：31.4 分（22.8 98.8）vs 43.3 分（17.0 61.0); $p=0.90$. 造影剤使用量 $\{1$ 血管造影: $3.9 \mathrm{~mL} / \mathrm{kg}$ （2.2 4.7） vs $3.9 \mathrm{~mL} / \mathrm{kg}(2.6 \sim 5.4) ; p=0.54$, (2)血管 造影 $+\mathrm{CT}: 3.9 \mathrm{~mL} / \mathrm{kg}(2.2 \sim 4.7)$ vs $5.9 \mathrm{~mL} / \mathrm{kg}(4.6 \sim$ $7.4) ; p=0.003\}$. 被曝線量 $(\mathrm{DAP} / \mathrm{kg}): 1.2(1.1 \sim 3.1)$ $\mathrm{Gy} \cdot \mathrm{cm}^{2} / \mathrm{kg}$ vs $0.8(0.4 \sim 2.4) \mathrm{Gy} \cdot \mathrm{cm}^{2} / \mathrm{kg} ; p=0.10$. な お, 手技時間はシースの挿入から抜去までとし, 造影 剂使用量は血管造影のみおよび CT との合算值を, 被 曝線量は血管造影のみで比較した。

実際の症例や画像を提示する.

\section{(1)症例 1 (Case No.1) (Fig. 3)}

35 週 $1777 \mathrm{~g}$ で出生した気管狭窄を合併した PAVSD の症例で, 生後 4 日に気管形成術, 2 か月時に体肺動 脈短絡術, 10 か月時に Rastelli 術施行. 術後より指
摘された分岐部肺動脈狭窄に対して，1歳 3 か月時に バルーン血管拡張術（BAP）を施行した. 3DRAに より, 左右肺動脈の 'ribbon stenosis'を一度に描出 し, 狭窄部位の詳細を評価したうえで, 各々に対し て至適角度で BAP を施行した。左肺動脈は, 最狭部 径 $2.6 \mathrm{~mm}$ ，参照血管径 $5.7 \mathrm{~mm}$ に対し，血管拡張用 バルーン Synergy ${ }^{\mathrm{TM}}$ (Boston Scientific, Natick, MA)

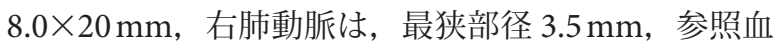
管径 $6.7 \mathrm{~mm}$ に Synergy ${ }^{\mathrm{TM}}$ (Boston Scientific, Natick, MA） $9.0 \times 20 \mathrm{~mm}$ を使用し，左室圧に対する右室圧 比（RVP/LVP）は $0.88 \rightarrow 0.64$ と低下した. C は Rastelli 術後退院前の CT 画像で同角度の 3DRA 画像を D に示した.

\section{(2)症例 2 (Case No.2)（Fig. 5)}

PAVSD/MAPCA の症例で, 前医にて 2 歳時に右 uniforcalization/体肺動脈短絡術, 当院にて 6 歳 


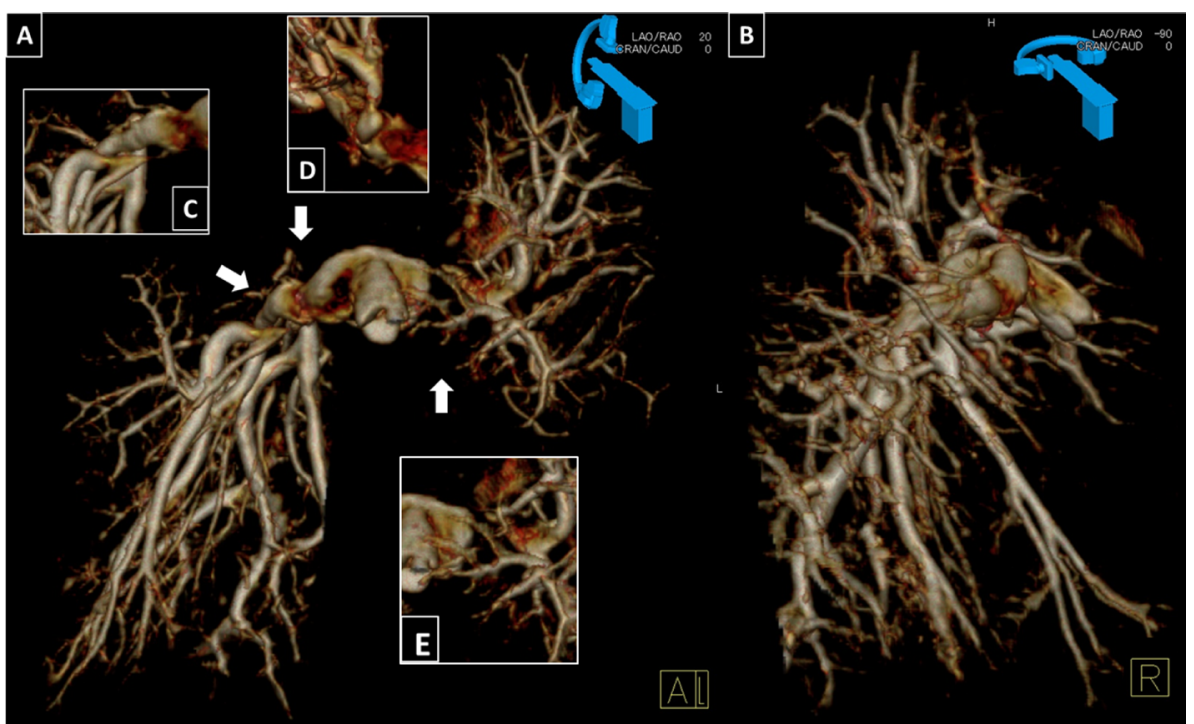

Fig. 5 Case No. 2

A: Antero-posterior view of the reconstructed 3DRA image of pulmonary atresia with ventricular septal defect and major aorto-pulmonary collateral arteries (MAPCA) repaired by palliative Rastelli procedure in a 7-years-old girl (LAO20\%CRA $0^{\circ}$ ). B: Lateral view of the reconstructed 3DRA image (RAO90 $/ C R A 0^{\circ}$ ) There were multifocal stenotic lesions after unifocalized pulmonary artery. C, D and $E$ indicate lesions viewed from each of the angles (C:LAO10 $/ C R A 0^{\circ}, \mathrm{D}: \mathrm{LAO}^{\circ} 80 / \mathrm{CRA} 20^{\circ}$, $\left.\mathrm{E}: \mathrm{LAO} 30^{\circ} / \mathrm{CRA} 0^{\circ}\right)$. 3DRA image allowed for better evaluation of the residual pulmonary area.

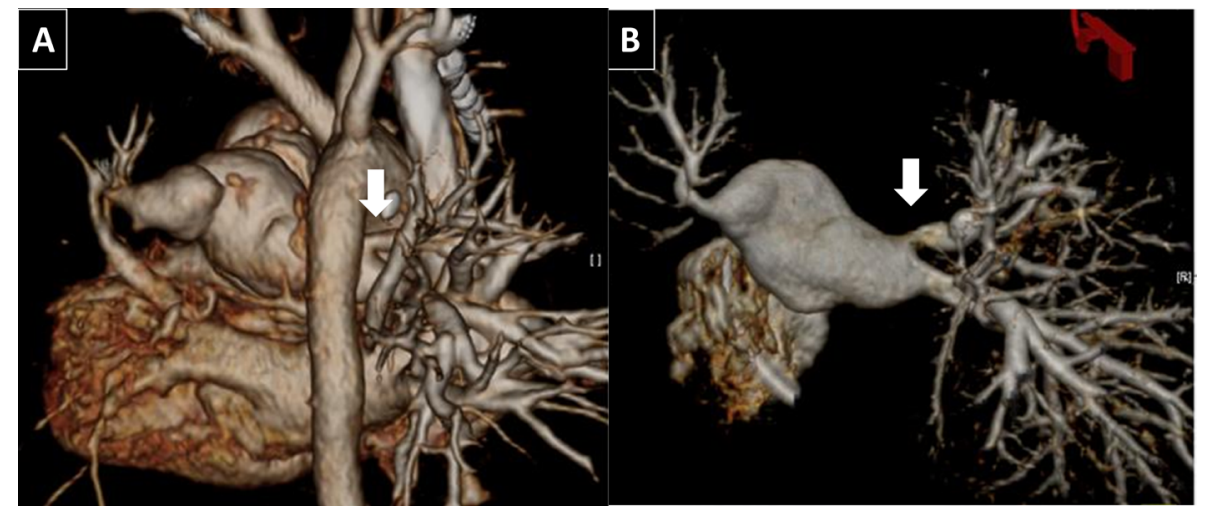

Fig. 6 Comparison of reconstructed 3D images of pulmonary artery

Reconstructed 3D images of pulmonary atresia with ventricular septal defect repaired by Rastelli procedure in a 4-yearsold boy. A: 3DCT and B: 3DRA. Arrows indicate right pulmonary artery stenosis.

時に肺動脈形成／体肺動脈短絡術, 7 歳時に左 uniforcalization/ASD 閉鎖/palliative Rastelli 術施行. 術後半年でカテーテル検査を施行した. 3DRAによ る 3D 再構築画像（A：正面像， B ：右側面像）を用 いて詳細な残存肺区域の推定を行い 8 区域と推定さ れた. 術後肺動脈狭窄は左右に複数箇所存在し, 肺区 域が少ないことからリスクの分散を考慮し半年間隔 で段階的な BAP を施行した。最初に左肺動脈(E), 最狭部径 $3.7 \mathrm{~mm}$, 参照血管径 $7.0 \mathrm{~mm}$ に対して Conquest $^{\mathrm{TM}}$ (Bard Peripheral Vascular, Inc., Tempe, AZ)
$8.0 \times 20 \mathrm{~mm}$, 半年後に右肺動脈 $(\mathrm{C})$, 最狭部血管径 $1.8 \mathrm{~mm}$, 参照血管径 $5.4 \mathrm{~mm}$ に対して, Mustang ${ }^{\mathrm{TM}}$ (Boston Scientific, Natick, MA) $6.0 \times 20 \mathrm{~mm}$, peripheral cutting balloon (Boston Scientific, Natick, MA) $6.0 \times 20 \mathrm{~mm}$, 右肺動脈 $(\mathrm{D})$, 最狭部血管径 $2.9 \mathrm{~mm}$, 参照血管径 $6.1 \mathrm{~mm}$ に対して Mustang ${ }^{\mathrm{TM}}$ (Boston Scientific, Natick, MA） 7.0/8.0×20 mm を使用した. 術 後, $\mathrm{SpO}_{2}: 95 \%$ 程度まで上昇がみられた。 
Table 3 Radiation exposure

\begin{tabular}{|c|c|c|c|c|c|c|c|c|c|}
\hline \multirow{2}{*}{ Case } & \multirow{2}{*}{ Diagnosis } & \multirow{2}{*}{ Age $(y)$} & \multirow{2}{*}{$\mathrm{BW}(\mathrm{kg})$} & \multicolumn{3}{|c|}{ Conventional angiography $(\mathrm{CA})$} & \multicolumn{2}{|c|}{ 3DRA } & \multirow{2}{*}{$\begin{array}{l}\text { DAPratio } \\
\text { 3DRA/CA }\end{array}$} \\
\hline & & & & Injection site & Angle & DAP* (Biplane) & Injection site & DAP & \\
\hline 2 & PAVSD/MAPCA & 9 & 26.3 & RVOT & $\begin{array}{l}\mathrm{LAO0} \cdot \mathrm{CRA0} \\
/ \mathrm{LAO} 90 \cdot \mathrm{CRAO}\end{array}$ & 231.8 & RVOT & 757.6 & 3.27 \\
\hline 5 & PAVSD/MAPCA & 3 & 12.1 & BTS & $\begin{array}{l}\mathrm{LAO0} \cdot \mathrm{CRAO} \\
\text { /LAO90 } \cdot \text { CRAO }\end{array}$ & 82.6 & BTS & 340 & 4.12 \\
\hline 6 & PAVSD/MAPCA & 6 & 15.5 & BTS & $\begin{array}{l}\mathrm{LAO0} \cdot \mathrm{CRA0} \\
\text { /LAO90 } \cdot \text { CRAO }\end{array}$ & 125.8 & BTS & 515.2 & 4.1 \\
\hline & & & & MAPCA*2 & $\begin{array}{l}\mathrm{LAO0} \cdot \mathrm{CRA0} \\
\text { /LAO90 } \cdot \text { CRAO }\end{array}$ & 254.7 & dAo & 522.6 & 2.05 \\
\hline 8 & PAVSD/MAPCA & 6 & 18.9 & PA & $\begin{array}{l}\text { LAO0 } \cdot \text { CAU } 45 \\
\text { /LAO90 } \cdot \text { CAU13 }\end{array}$ & 179.9 & RVOT & 518.7 & 2.88 \\
\hline 9 & PAVSD/MAPCA & 5 & 14.6 & PA & $\begin{array}{l}\text { RAO7 } \cdot \text { CAU45 } \\
\text { /LAO90 } \cdot \text { CAU14 }\end{array}$ & 187.4 & RVOT & 409.6 & 2.19 \\
\hline 11 & TOF & 2 & 13.3 & PA & $\begin{array}{l}\text { LAO13 · CAU45 } \\
\text { /LA090 • CAU11 }\end{array}$ & 164.9 & PA/LSVC & 360.8 & 2.19 \\
\hline 14 & PAVSD & 1 & 7.5 & PA & $\begin{array}{l}\text { LAO8 } \cdot \text { CAU41 } \\
\text { /LAO90 } \cdot \text { CAU15 }\end{array}$ & 170.9 & RVOT & 313.3 & 1.83 \\
\hline
\end{tabular}

*DAP $=$ frontal view and lateral view $\left(\mu \mathrm{Gy} \cdot \mathrm{m}^{2}\right)$ DAP: dose area product $\left(\mathrm{mGy} \cdot \mathrm{m}^{2}\right)$, PAVSD: pulmonary atresia with ventricular septal defect, MAPCA: major aorto-pulmonary collateral arteries, TOF: tetralogy of Fallot, RVOT: right ventricular outflow tract, PA: pulmonary artery, BTS: Blalock-Taussig shunt, dAo: descending aorta, LSVC: left superior vena cava, CRA: cranial, CAU: caudal

Table 4 Intervention of Rastelli procedure (3DRA vs CT)

\begin{tabular}{|c|c|c|c|}
\hline \multirow{2}{*}{$\mathrm{N}$} & 3DRA & CT & \multirow{2}{*}{$p$-valve } \\
\hline & 5 & 10 & \\
\hline Diagnosis & $\begin{array}{l}\text { PAVSD/MAPCA:2, IAA:1, } \\
\text { PAVSD:1, DORV/PA:1 }\end{array}$ & $\begin{array}{c}\text { TGA3:2, TOF/MAPCA:2, DORV/PA:2, } \\
\text { PAVSD/MAPCA:1, IAA:1, TAC:1, APVS:1 }\end{array}$ & \\
\hline Age (year) & $9.8(1.1-12.1)$ & $8.1(2.7-15.8)$ & 0.71 \\
\hline Body weight (kg) & $41.7(8.6-60.1)$ & $21.2(14.2-49.8)$ & 0.71 \\
\hline Procedure time (min) & $121(114-212)$ & $121(76-196)$ & 0.46 \\
\hline Fluoroscopy time (min) & $31.4(22.8-98.8)$ & $43.3(17.0-61.0)$ & 0.9 \\
\hline $\mathrm{DAP}\left(\mathrm{Gy} \cdot \mathrm{cm}^{2}\right) / \mathrm{BW}(\mathrm{kg})$ & $1.2(1.1-3.1)$ & $0.8(0.4-2.4)$ & 0.1 \\
\hline Contrast media $(\mathrm{mL} / \mathrm{kg})$ : Angiography & $3.9(2.2-4.7)$ & $3.9(2.6-5.4)$ & 0.54 \\
\hline Contrast media $(\mathrm{mL} / \mathrm{kg})$ : Total & $3.9(2.2-4.7)$ & $5.9(4.6-7.4)$ & 0.003 \\
\hline
\end{tabular}

TGA: transposition of the great arteries, PAVSD: pulmonary atresia with ventricular septal defect, MAPCA: major aorto-pulmonary collateral arteries, DORV: double outlet right ventricle, PA: pulmonary atresia, IAA: interruption of aortic arch, TOF: tetralogy of Fallot, TAC: truncus arteriosus, APVS: absent pulmonary valve syndrome, PPS: peripheral pulmonary stenosis

\section{考 察}

\section{DRA の画像特性，適応}

3DRA は目的部位によって造影剤注入用カテーテル の位置や造影剤注入, 撮影タイミング, 心室オーバー ドライブを設定することにより関心領域, 特に動脈性 病変を強調した画像描出が可能となる. 特にオーバー ドライブは，心拍出量を低下させ造影剂の拡散を抑え ることで, 回転撮影終了までの不明瞭化を防ぐととも に，心収縮による motion artifactを抑え，目的部位 への造影剤の直接注入と合わせて, 血管壁の性状をよ
り明瞭に描出することを可能とする ${ }^{10)}$.

また，一般的な三次元画像と同様に任意の角度から 観察が可能であり，Zahn らの報告 ${ }^{10)}$ の多発性肺動 脈狭窄のような複数病変の同時描出や Berman らの報 告 ${ }^{12)}$ のような屈曲の強い血管の描出にも優れた効果 を発揮する.

加えて 3DRA の有用性として人工物留置例, 例え ば脳動脈瘤術後症例でクリップによるハレーションの 影響で CT にて観察困難な病変も良好な描出が可能と 報告されている ${ }^{13)}$.

これらをふまえ当院では, Rastelli 術後の左右分岐 
部狭窄や多発性の未梢肺動脈狭窄といった複数病変を 有する症例, unifocalization 後 MAPCA 症例の統合 化肺動脈のように屈曲やねじれなど複雑な形態をもっ た血管病変, 人工弁置換や対象血管近傍にコイル，ク リップ，胸骨ワイヤーなどが使用された病変において 3DRAは効果を発揮すると考え, 適応を選択している.

\section{DRA の有用性}

3DRA が小児循環器領域, 特にインターベンション において有用と考えられる点は主に，任意の角度から の立体的な病変観察, 迅速な $3 \mathrm{D}$ 再構築抢よび計測, ワーキングアングルの選別およびロードマップ, 被曝 線量, 造影剂使用量の低減の 4 点があげられる.

\section{(1)任意の角度からの立体的な病変観察}

3DRA では三次元化により 3DCT と同様に任意の 角度から立体的な病変観察が可能となるため, 事前に 造影角度を考慮する必要がなくなる．また従来の二 方向性撮影に比べ 70 90\%の症例で従来法を上回る 病変に関する新たな情報が得られたと報告されてい $3^{12,14-16)}$. 我々の検討でも全体の $75 \%$ で従来法を上 回る質の画像情報が得られており同様の結果であっ た. 'ribbon stenosis'などの従来法では描出の難しい 病変（Figs. 2，3）や複数回の撮像が必要であった多 発性の病変（Fig. 5）も一度に可視化され，立体的な 狭窄形態の評価が可能となった. Table 2 にあるよう に，従来の二方向シネ動画を上回る評価と考えられる が, その理由としては, 多角的, 立体的に画像再構築 されているばかりでなく, オーバードライブなどの工 夫により血管形態全体の輪郭を描出していることが, 病変の性状把握や肺区域数の把握に優位性が高いため と考えられた。従来法では圧較差等から存在が示唆 されながら読影者の経験に基づく想像や， CT や心工 コー図といった他のモダリティからの類推に頼ってい た病変も明瞭に可視化することで, より視覚的に客観 的な診断，評価が可能になると考えられる.

\section{(2)迅速な三次元再構築および計測}

3DRA の三次元再構築は概ね 5 分以内に可能で, 迅 速な再構築により術中モニタリングとして効果を発揮 する ${ }^{10,16)}$ ．迅速性は撮影範囲を限定することで CT の ように広範囲の胁骨や脊椎等の処理が不要となる点に 起因する.このため事前の CT など三次元撮影が不要 となり, 特に状態が不安定な小览例で, 複数回の鎮静 や造影剤使用によるリスクを軽減することが可能とな る.

血管径の計測は, 過去の $3 \mathrm{D}$ 再構築画像と従来の二 方向性血管造影での血管径は同等との報告 ${ }^{16,17)}$ に基
づき，3D 再構築画像で角度を調節した最狭部位を測 定している．また，血管径の計測にあたっては動脈管 などで経験するように心周期の影響を受けることが知 られている. 3DRA では，心室オーバードライブに より心収縮による血管拍動の影響が低減され，CTに 比して狭窄部位の過大評価を防げる可能性が示唆され た.この点はより精密なインターベンションに繋がる と思われた。

\section{(3)ワーキングアングルの選別およびロードマップ}

インターベンションは, 病変観察の最適角度を決定 し，至適造影角度で施行される．3DRAではどんな 病変でも一度の造影で最適角度の算出が可能で, 複数 病変の同時評価も可能である。 またインターベンショ ンの補助的ツールとして透視画像とのオーバーレイ表 示によるロードマップや同一装置の利点をいかした 透視画像と 3D 画像の連動性がある.Cアーム角度, 画像サイズ, 寝台位置の変更に $3 \mathrm{D}$ 画像もリアルタイ ムで追従するため，多角性を維持したままでより迅 速な治療が可能となる.この Live 3D roadmap は, 実際にステント留置や経カテーテル的大動脈弁留置術 (transcatheter aortic valve implantation; TAVI) など の弁留置での有用性が報告されている ${ }^{18,19)}$.

\section{(4)被曝線量および造影剤使用量の低減}

3DRA では, 多角的観察のため従来法のような複 数回の撮像が不要となり血管造影検査 1 セッション あたり被曝線量や造影剂総使用量の低減が期待され ている。この点に関しては実際に様々な報告がされ ているが結論には至っていない. Corredoria ら ${ }^{20)}$ は 3DRA の使用により総 DAP が診断カテーテル検査で は $33 \%$ ，インターベンションでは $16 \%$ 増加としたと 報告, Glockler ら ${ }^{21)}$ は 3DRA の使用により従来の二 方向性撮影に比べて透視時間は減少，総 DAP，造影 剂使用量は同等としている。一方で主に冠動脈の領 域では総被曝線量, 造影剤使用量とも減少したと報 告 ${ }^{22-24)}$ されており, Zahn ${ }^{10)}$ や Berman ${ }^{12)}$ は 3DRA 使用時の総被曝線量，造影剂使用量は従来法と同等 レベル以下に抑えうるとしている，また， Glatz" ${ }^{9)}$, Schwartz ら ${ }^{19)}$ は，CT 併用に比して血管造影検査 1 セッションあたりの総被曝線量，造影剤使用量とも同 等以下と報告している。

自験例では，被曝線量に関して 3DRA1 回が通常の 二方向撮影 2.8 回分に相当した. また, CT 群との比 較においては，血管造影検査 1 セッションあたりの 手技時間や透視時間，被曝線量は同等であったが総造 影剤使用量は低減されていた。3DRA 施行により手技 時間や透視時間の延長がみられない理由としては，至 
適角度や狭窄部位の正確な計測に加えて同一機器の使 用によるCアームおよび寝台のスムーズな移動等に よる 3DRA 手技以外の時間短縮が可能であった点に 起因すると考えられた。ささら被曝線量に関しては, CT 撮影分を加味すると総被曝線量として低減の可能 性も示唆された. この点に関しては, 今後, シングル プレーンの積極的な使用や 3DRA のフレーム数, フ レームあたりの放射線量など撮影方法の調整により更 なる低減が可能になると思われ, 更なる症例の蓄積が 必要と考えられた。

\section{DRA の課題}

3DRA は撮像範囲を限定した画像となるため, 静 脈, 心室, 心房などを含む全体の描写には向かない. また, Truong ら ${ }^{25)}$ は気道の描出を報告しているが, 当院では再構築時間を要することもありリアルタイム での気道情報の提供には至っていない.したがって周 辺構造物を含めた情報の必要時, 特に直近での再開胸 を含む外科手術の可能性がある場合や気管との位置関 係が問題になる場合などは現状では CT を選択すべき と考えている。一方で, 気管との位置関係が問題とな るステント留置などでこそ, 3DRA の利点であるワー キングアングルやロードマップ等が効果を発揮しうる ため, 気道描出のリアルタイム性を追求するとともに 不足情報を従来の二方向性撮影から補填するなどして 適応を拡大していくべきと考えている。

また, 撮影条件としてペーシングや呼吸停止が必要 で, Cアームが回転するため麻酔器等周辺環境の整備 が重要となる，そのため通常の血管造影に比べて関わ る人員も多くなるが, 多職種で手順を確認し, 安全に 施行できるようチームで協力体制をとることが大切に なる，その上で症例を積み重ねることでより短時間で 安全な撮像が可能になると思われる。

\section{結 論}

3DRA は, 小児循環器領域でも安全に施行可能で従 来法にはない広角的, 立体的な画像構築により, より 客観的な診断, 評価に寄与する可能性が示唆された。 さらにインターベンションにおいては, 手技時間, 透 視時間, 造影剂使用量, 被曝線量などの面で従来法と 比べ遜色なく, CT 併用群に比し総造影剤使用低減が 可能であった.

\section{利益相反}

本論文に関連し，開示すべき利益相反はありません.
付 記

この論文の電子版にて動画を配信している.

\section{引用文献}

1) Benndorf G, Klucznik RP, Strother CM: Angiographic computed tomography for imaging of underdeployed intracranial stent. Circulation 2006; 114: E499-E500

2) Engelhorn T, Struffert T, Richter G, et al: Flat panel detector angiographic CT in the management of aneurysmal rupture during coil embolization. Am J Neuroradiol 2008; 29: 1581-1584

3) Jou LD, Mohamed A, Lee $\mathrm{DH}$, et al: 3D rotational digital subtraction angiography may underestimateintracranial aneurysms: Findings from two basilar aneurysms. Am J Neuroradiol 2007; 28: 1690-1692

4) Biasi L, Ali T, Hinchliffe R, et al: Intraoperative DynaCT detection and immediate correction of a type la endoleak following endovascular repair of abdominal aortic aneurysm. Cardiovasc Intervent Radiol 2009; 32: 535-538

5) Wallace MJ: C-arm computed tomography for guiding hepatic vascular Interventions. Tech Vasc Interv Radiol 2007; 10: 79-86

6) Nolker G, Gutleben KJ, Marschang H, et al: Three-dimensional left atrial and esophagus reconstruction using cardiac C-arm computed tomography with image integration into fluoroscopic views for ablation of atrial fibrillation: Accuracy of a novel modality in comparison with multislice computed tomography. Heart Rhythm 2008; 5: 1651-1657

7) Biasi L, Ali T, Thompson M: Intraoperative dynaCT in visceral-hybrid repair of an extensive thoracoabdominal aortic aneurysm. Eur J Cardiothorac Surg 2008; 34: 12511252

8) Meyhoer J, Ahrens J, Neuss M, et al: Rotational angiography for preinterventional imaging in transcatheter aortic valve implantation. Catheter Cardiovasc Interv 2012; 79: 756-765

9) Glatz AC, Zhu X, Gillespie MJ, et al: Use of angiographic CT imaging in the cardiac catheterization laboratory for condenital heart disease. JACC Cardiovasc Imaging 2010; 3: $1149-1157$

10) Zahn EM: The Emerging Use of 3-dimensional rotational angiography in congenital heart disease. Congenital Cardiology Today 2011; 9: 1-13

11) Ellis AR, Mulvihill D, Bradley SM, et al: Utility of computed tomographic angiography in the pre-operative planning for initial and repeat congenital cardiovascular surgery. Cardiol Young 2010; 20: 262-268

12) Berman DP, Khan DM, Gutierrez Y, et al: The use of three-dimensional rotational angiography to assess the pulumonary circulation following cavo-pulmonary connection in patients with single ventricle. Catheter Cardiovasc Interv 2012; 80: 922-930

13) Budai C, Cirillo L, Patruno F, et al: Flat panel angiography images in the post-operative follow-up of surgically clippedintracranial aneurysms. Neuroradiology 2014; 27: 203-206

14) Moesler J, Dittrich S, Rompel O, et al: Flat detector computed tomography in diagnostic and Interventional 
pediatric cardiology. RoFo Fortschr Geb Rontgenstr Nuklearmed 2013; 185: 446-453

15) Glockler M, Koch A, Greim V, et al: The value of flat-detector computed tomography during catheterisation of congenital heart disease. Eur Radiol 2011; 21: 2511-2520

16) Glockler M, Koch A, Halbfaß J, et al: Assessment of cavopulmonary connections by advanced imaging: Value of flat-detectorcomputed tomography. Cardiol Young 2013; 23: $18-26$

17) Borik S, Volodina S, Chaturvedi R, et al: Three-dimensional rotational angiography in the assessment of vascular and airway compression in children after a cavopulmonary anastomosis. Pediatr Cardiol 2015; 36: 1083-1089

18) Fagan T, Kay J, Carroll J, et al: $3 \mathrm{D}$ guidance of complex pulmonary artery stent placement using reconstructed rotational angiography with live overlay. Catheter Cardiovasc Interv 2012; 79: 414-421

19) Schwartz J, Neubauer A, Fagan T, et al: Potential role of three dimensional rotational angiography and C-arm $\mathrm{CT}$ for valvular repair and implantatio. Int J Cardiovasc
Imaging 2011; 27: 1205-1222

20) Corredoria E, Vano E, Ubeda C, et al: Patient doses in paediatric Interventional cardiology: Impact of 3D rotational angiography. J Radiol Prot 2015; 35: 179-195

21) Glockler M, Halbfa $\beta$ J, Koch A, et al: Multimodality $3 \mathrm{D}$-roadmap for cardiovascular interventions in congenital heart disease: A single-center, retrospective analysis of 78 cases. Catheter Cardiovasc Interv 2013; 82: 436-442

22) Akhtar M, Vakharia KT, Mishell J, et al: Randomized study of safety and clinical utility of rotational vs. standerd coronary angiography using a flat-panel detector. Catheter Cardiovasc Interv 2005; 66: 43-49

23) Empen K, Kuon E, Hummel A, et al: Comparison of rotational with conventional coronary angiography. Am Heart J 2010; 160: 552-563

24) Klein AJ, Garcia JA, Messenger JC, et al: Rotational coronary angiography. Cardiol Clin 2009; 27: 395-405

25) Truong U, Fagan T, Deterdling R, et al: Use of ratational angiography in assessing relationship of the airway to vasculature during cardiac catheterization. Catheter Cardiovasc Interv 2015; 86: 1068-1077 